\title{
The Underlying Ideologies in News Articles: The Study Through the Use of Direct Quotations and Lexical Choices in an English Newspaper in Thailand and an American Newspaper
}

\author{
Nalin Viboonchart ${ }^{1} \&$ Chanika Gampper ${ }^{1}$ \\ ${ }^{1}$ Language Institute, Thammasat University, Bangkok, Thailand \\ Correspondence: Nalin Viboonchart, Language Institute, Thammasat University, Bangkok, Thailand. Tel: \\ 68-26-133-1013.E-mail: nalin.vib@gmail.com; chanivad@yahoo.com
}

Received: May 31, 2014 Accepted: June 5, 2014 Online Published: July 11, 2014

doi:10.5539/ass.v10n15p187 URL: http://dx.doi.org/10.5539/ass.v10n15p187

\begin{abstract}
The qualitative study investigates the different ideologies underlying in news articles on the red shirt demonstration during March-May, 2010 that were published in the Bangkok Post (BKP) and the New York Times (NYT). The Critical Discourse Analysis (CDA) is used as the major instrument to analyse news texts. The research studies two aspects, namely, direct quotations and lexical choices of word with a different connotation. The study found that the ideologies in both newspapers are transmitted through these linguistic perspectives. NYT tends to use direct quotations and lexical choices to support and argue for the demonstration of the red shirt protesters, whereas BKP is likely to take side of the Thai government. The demonstration in 2010 in NYT's view seem to be the fighting for the true democracy by the poor, who are the majority of the country's electoral bloc, while BKP does not support the violence caused by the Red Shirt protesters.
\end{abstract}

Keywords: Critical Discourse Analysis, direct quotations, lexical choices, Bangkok Post, New York Times

\section{Introduction}

\subsection{Introduce the Problem}

News articles nowadays are not limited to only local news in particular countries, but there are international news, enabling people from elsewhere in the world to know the movement in other countries shortly. Besides, a newspaper is not also sold in one country, but is spread in many locations. Hence, there is no boundary for the news consumption.

To understand ways the news articles are reported, the readers have to understand that the social background of the writers and the institution of each media, beliefs and values in one country also have an influence on the use of language. Journalists with different social background, races, beliefs and values may report the same event in the different news angles. As explained by Richardson (2007), society and value judgment are expressed by words, which has both connotation and denotation meanings. Eggins (1994) also has a similar opinion that the language we use always conveys an attitude and makes a role. So, the different use of words also means the different meanings the senders want to encode in the texts. And this is why Fowler (1991) maintains that language in news is not neutral but socially constructed.

The different writing styles and linguistics strategies used in writing news articles published in different countries or different types of newspapers are studied during the past decades, reflecting the more interests in linguistics analysis in the media. The different styles contain bias and illustrate the different ideologies presented in the media as well. This difference sometimes lead to the misunderstanding when local people read news articles written by foreign media or foreigners read news stories written by local journalists.

\subsection{Explore Importance of the Problem}

1) Ideology

Most of the definition of "ideology" depicts the influence of society and experience towards the language use. "Ideology" appears to be the relationship between idea and social influence. For this present research, ideology is related to the linguistic study based on Paltridge (2006)'s illustration that the use of discourse contains and reproduces ideologies. 
The researcher who study ideology cannot skip the theory of van Dijk. He explains about ideology in many of his books and research papers. In summary, van Dijk $(1995,1998)$ demonstrates that ideologies are shared social representations that have specific functions for groups. It is not the tangible idea but abstract mental systems that organise such socially shared attitudes (van Dijk, 1995). Also, It is not just the sets of beliefs, but socially beliefs of groups (van Dijk, 1998) that represent the group's identity, tasks, goals, norms, values, positions and resources (van Dijk, 1995). Similar to van Dijk, Fairclough (1995) defines ideologies as shared social representations that have specific social functions for groups.

Media discourse is not only the way that underlying ideologies of the language users, journalists, can be reproduced in texts, but also the way to convince the readers to believe or to see in the same direction of the writers. "The expression of ideology in discourse is usually more than just an explicit or concealed display of a person's beliefs, but mostly also has a persuasive function: speakers want to change the mind of the recipients in a way that is consistent with their beliefs, intentions and goals" (Fairclough, 1995, p 263).

Regarding this discussion, Fairclough does not see media discourse as only the way to contain ideologies in texts, but as the tool to reproduce ideologies and transfer the writers' beliefs, attitudes and values to convince the readers. Thus, Fairclough sees the implication and significance of the media discourse analysis in uncovering underlying ideologies that the journalists might put in the texts.

\section{2) Discourse and Ideology}

Since the language is socially and culturally constructed, it will then present the ideologies of the language encoders. Eggins (1994) discusses that no matter what genre or the situation of the texts, the ideological position will have a power towards the language use.

The mass communication theory in news media is recognised that news should be free from opinions and the news contents must be neutral. However, a number of mass communication theorists believe that no news is neutral. Fowler (1991) states that the contents in newspapers contain beliefs, values, theories, proposition, and ideology.

In case of news articles, the writers who are in the different societies with the distinctive social background, attitude, beliefs and values are likely to have the different views towards the same stories. The audiences will experience this difference obviously when they compare the same event written by the journalists who are in different countries or societies. Richardson (2007) explains that the news construction is closely relevant with the power of social groups. It is not a surprise that newspapers in the United States or the United Kingdom will present the different news angles towards the same events with those in Thailand.

When one situation that is valuable to be news happens, the journalists cannot report all the details of any particular situation. They will pick the interesting issue in accordance with the news worthiness criteria such as the proximity of the situation, the oddity, the public interest, and conflicts. Fowler (1991) demonstrates this point that news articles are not the representation of the real world since the news angles are selective. Some topics will be chosen to present in the news articles. Fairclough (1995: p47) explains this in a clear picture that "people always make such evaluations from particular positions and points of view". The social background then takes part in shaping the news angles, and the different news angles also paint the different view among the audiences towards the same stories.

How the messages are illustrated through texts in newspapers and what attitude, values and beliefs are put in the articles are the selection process of the journalists (Fairclough, 1995). He discusses that the selections will happen with language forms, and lexical and grammatical choices. The different grammatical forms, the sentence structures and words used to tell the news stories are "potentially ideologically significant". It can carry ideological meanings through the texts (Fairclough, 1995).

Hence, in order to analyse language in news, linguistic tool like Critical Discourse Analysis (CDA) now is widely used for that purpose. Richardson (2007) argues that CDA, which is used to achieve this goal, can help disclose a relationship between the text and societies. And many studies in the past decades have been done by this tool. Under the CDA, to study direct quotations and the choices of words are two of many linguistic tools to uncover the ideologies in news articles.

\section{3) Direct Quotations}

In news articles, there are both direct and indirect quotations. This study focuses on only direct quotations, which contain the exact words from news sources. Manning (2001) states that direct quotations contain the exact words newsmakers delivered. Fedler (1973) says that when readers see sentences in quotation marks, it means that they are reading the exact words from newsmakers rather than from the news writer. 
Bell (1991) explains that the meanings of whatever the sources said may be the main factor for the journalists to use direct quotations in order not to make mistake from rewording. Another function of direct quotations is to spice up the story by using the newsmaker's own words. Similar to Manning, Fedler (1973) sees direct quotations as the way to convey the most dramatic moments in the story. Harris \& Spark (1997) summarise the function of direct quotations interestingly that "The advantage of direct quotation are accuracy and liveliness (p69).

The aforementioned explanations are the direct quotations in media scholars' views. Considering another angle, Davis (1985) as cited in van Dijk (1985) argues that direct quotations are not neutral. "Quotations also contain ideological bias" (Davis, 1985). This is because direct quotations are under the selection process. Journalists have to consider the most important issues and wordings from their news sources to be put in the direct quotations. And when it comes to the selection process, it bases on the journalists' knowledge and experiences (Manning, 2001). Thus, As the present research aims to study the underlying ideologies in newspaper, it is valuable to look at direct quotation as another elements for the analysis.

\section{4) Lexical Choices}

The interesting thing in studying word choices is that it can examine the different ideological meanings from the words the journalists choose. In language use, there is a selection process of the lexical and grammatical choices, and there is a reason why the users pick this word instead of others (Fairclough, 1995). Pape \& Featherstone (2005) also demonstrate that when choosing any words, journalists is making decisions how the facts will be presented through the words they select. Fairclough (1995) sees the importance of text analysis as part of socio-cultural analysis of media, which can tell us the ideologies, power relations and cultural values underlie in certain texts as he states that "the linguistic choices that are made in texts can carry ideological meanings" (p25).

Van Dijk (1995 and 1998) also includes lexical choices as one of the important linguistic tools to contain ideologies in texts and talks. He states that language users will select different words when portray things, events, situations, people or actions. Because of the different attitudes, beliefs, values and opinions of language users, words used in the communication are also different (van Dijk, 1995, 1998). The popular example van Dijk (1995) uses to explain the importance of lexicalisation is the pair of words between "terrorist" versus "freedom-fighter", which the former gives the negative meaning, while the latter makes the readers feel more positive. Lexical choices are the major means to convey ideological meaning in discourse (van Dijk, 1998). Hence, van Dijk (1998) points out that "Lexical analysis is therefore the most obvious (and still fruitful) component in ideological discourse analysis" (p205).

\subsection{Describe Relevant Scholarship}

Many research that study ideology were done by non-native speakers. Some of them are the comparative analysis between the text written by the native speakers and non-native ones, and some are the analysis of the written texts composed by native speakers, but the contents of the texts were something about the situation in the countries where the researchers are the citizen.

Sai-hua Kuo (2003) is known for his study that looks in to the function of quotations to uncover the underlying ideologies in news articles. His study "Languages Ideology: Analyzing Quotations in Taiwanese News Discourse" focuses on analysing quotations in the news reports on two ideologically opposed newspapers in Taiwan - United Daily News and Liberty Times. The news article is about the President Chen Shui-bian's statement "one country on each side". The research found the significant differences in quotation used in the news articles that the newspapers tend to quote the sources that represent the sides that each newspapers prefer. This is the way to use quotations to convey the messages that support the ideologies of each newspapers and each side. The findings can prove that news articles are not neutral and objective.

The latest research in CDA is of Bailie (2013), whose research title is "Meaning Making in the News: A Discourse Analysis on Global Protest". He studied news articles in NYT covering three protests in Tunisia, North America and Greece during 2010-2011. The objectives of the study is to explore how discourses in NYT, which is the mainstream media of the United States, are formed in the way that it wants the world to see and excludes alternative views, and how meanings of these example concepts - democracy, revolution, protest and dissent - are made. These three protests in different countries have one thing in common; that is the uprising of people and the failure of the economic policy. Bailie used the approach of Laclau and Mouffe in Hegemony and Socialist Strategy (1985) to broaden notion of what discourse is describing. Their approach deals with the notion of the working class standing up against the capitalism. His study shows that meanings in the news articles are made through the word used to describe people in news and some information are either include or exclude in order to let the world see in what the journalists would like the world to see. 
1) Critical Discourse Analysis Study Related to Demonstration in Thailand in 2010

In 2011, Chirawat Chana has done his research entitled "Comparative Rhetoric of News Reports in Thailand and The USA. With a focus on Thai Political Written Discourse". His research concerns the different political news discourse, focusing on three main angles - cohesion, the discourse structure of news articles, and discriminatory discourse structures and strategies. The Bangkok Post and The Nation were used in the study as the representatives of the Thai English language newspapers, whereas The New York Times, Newsweek and Time magazine represent the American side. One angle of the analysis is to study discriminatory discourse structures and strategies in between the Thai English language newspapers and American newspapers, which found that the negative attribution are used more frequently in the American newspapers, reflecting that the American views the protest negatively than the Thai media, which is likely to be fact-oriented reports.

Although there is a study about the critical discourse analysis on the demonstration in Thailand in 2010 like the aforementioned research, it touches a bit about the sociolinguistic analysis. This leads to the current study, which does more on the sociolinguistics to discover the underlying ideologies in news articles comparing between BKP and NYT and which linguistics tools are used to contain the ideologies.

\section{Method}

\subsection{Participant Characteristics}

To do a CDA of news articles in an American newspaper and English language newspaper in Thailand, the study was designed to choose one newspaper published in the United States (the US) and one from Thailand as texts for the study. The study set the criteria for choosing one newspaper for each side, which the samples used in this study should represent the majority of readers in each country, report the daily situations of the Red Shirt demonstration in Thailand, report news directly by correspondents in Thailand in order to present the real views of the journalists and for the American side, the news articles should be easily accessed through the Websites. The study finally got BKP as the representative of English newspaper in Thailand and NYT as the representative of American newspaper.

\subsection{Sample Size}

Another criteria was also set to select sample texts for each newspaper. The study was designed to use 10 news articles for each side, which each pair of the sample texts must be published on the same days and write about the same events.

\subsection{Research Design}

\section{1) Direct Quotations}

Regarding the direct quotations, all quotations in the samples are investigated and coded depending on the sayers (the government and the Red Shirt protesters). The results are analysed after the coding.

\section{2) Lexical Choices}

The research created two corpus for BKP and NYT each to study lexical choices. Antconc 3.2.1 is the corpus programme used in the research. In each corpus, all words were ranked automatically by the Antconc programme. The benefit of using corpus as an linguistic tool is that it can sort out the frequencies of each word used in BKP and NYT. The research considered an chose the lexical choices for the study by looking at the word frequencies. After that, the study considered the different ranking of words and find interesting pairs of lexical choices.

The study got two pairs of different words - wounded and injured, rioters and protesters, and protesters and people that were used in the similar meanings. The study did further analysis of each pair and group. The Oxford Advanced Learners Dictionary was used as a tool to find the meanings of each words and support the reasons why each words were used differently in BKP and NYT.

\section{Results}

\subsection{Direct Quotations}

BKP tends to pay more attention to the government sides when it writes direct quotations in the news articles about the red shirt demonstration, whereas NYT is likely to give its space to the protesters side. Direct quotations about the Thai government in BKP are 22 quotations out of 37 totally, accounting for $59.46 \%$. NYT has 47 quotations out of 77 that deal with the red shirt protesters, representing $61.04 \%$ of total direct quotations. BKP has 15 quotations said by the red shirt protesters side, accounting for $40.54 \%$, whereas NYT has 22 quotations 
from the government side, accounting for $28.57 \%$, lower than when BKP gives space to the protesters side. The results are in the table1 below,

Table 1. Direct Quotation Results in BKP and NYT

\begin{tabular}{lcccccc}
\hline \multirow{2}{*}{ Newspapers } & \multicolumn{2}{c}{ Government } & \multicolumn{2}{c}{ Protesters } & \multicolumn{2}{c}{ Others } \\
\cline { 2 - 7 } & Frequencies & percentage & Frequencies & Percentage & Frequencies & Percentage \\
\hline BKP & 22 & 59.46 & 15 & 40.54 & 0 & 0 \\
NYT & 22 & 28.57 & 47 & 61.04 & 8 & 10.39 \\
\hline
\end{tabular}

More important than the frequencies of the quotations is the meaning in the quotations. The research found that the quotations said by the red shirt protesters side in NYT tend to paint good image of the red shirt demonstrators and some are talking negatively towards the government side, while the quotations in BKP that deal with the government are likely to support the government.

\section{1) Direct Quotations in BKP}

The example direct quotations in BKP that are likely to support what the government did during the political turmoil are as follow,

1. "The government and I are duty-bound to resolve the problems, restore peace and maintain justice for the country," he said. (BKP4)

2. "The security forces are trying to exert more pressure on the protesters without using force and we have no policy to cause violence in the rally area." (BKP5)

3. "I have made a decision in the best interests of the country. My decision will not run counter to the principle of the rule of law." (BKP8)

There are 6 quotations out of 22 said by the government side in BKP, or $27.27 \%$, that seem to paint negative image to the red shirt protesters. Some of these quotations are as follow,

1. "Negotiations can happen if the protest stops and its leaders surrender. But if this does not happen, they [the UDD leaders] should tell the mobs to stop the rioting and the burning of the city and tyres. As Mr Natthawut said he could issue orders, does this mean that he ordered the mobs to create violence?" Mr Korbsak asked. (BKP3)

2. "I cannot accept it any more. Red shirt people, please stop. Don't make more trouble." (BKP4)

3. "All terrorists must end their action otherwise the government will use decisive measures against them," the centre warned. (BKP1)

\section{2) Direct Quotations in NYT}

The example direct quotations in NYT that are likely to support what the Red Shirt protesters during the political turmoil are as follow,

1. "Although the road is rough and full of obstacles, it's our duty to honor the dead by bringing democracy to this country." (NYT2)

2. "This land belongs to the people," read a message painted on one vehicle. (NYT2)

3. "We all want this to end peacefully," said Kwanchai Praphana, one of the protest leaders, in an interview at the rally site. (NYT8)

There are 8 quotations out of 47 said by the protesters side in NYT, or $17.02 \%$, that seem to paint negative image to the government side. These quotations are as follow,

1. "If they come, we have the right to fight back. We can't just let them kill us and do nothing." (NYT5)

2. "We are afraid for the soldiers, too," she said. (NYT5)

3. "Things will be out of control if a crackdown happens, no matter what plans are," he said. (NYT6)

\subsection{Lexical Choices}

To study the lexical choices, corpus has been used to find out the word with high and low frequencies. The research found some words used in BKP and NYT with different frequencies appeared in the news articles. There are 3 pairs of words

1) wounded and injured 
2) protesters and people

\section{1) Wounded-Injured}

The frequencies of the word wounded and injured occurred in BKP and NYT are different. As can be seen in the table 2, the word wounded in NYT is in the first band of 100 words with the highest frequencies, while that in $\mathrm{BKP}$ is in the third band of the highest frequencies.

Table 2. The Comparison of Frequencies and Rankings of the Word "Wounded" in BKP and NYT

\begin{tabular}{lrl}
\hline & BKP & NYT \\
\hline Frequency & 4 & 17 \\
Ranking & 378 & 75 \\
\hline
\end{tabular}

Instead of using the word wounded in the news article, BKP prefers to use the word injured. The word injured is ranked 75 in BKP with 14 occurrences, while that in NYT is ranked 379 with 4 occurrences. The frequencies are shown in the following.

Table 3. The Comparison of Frequencies and Rankings of the Word "Injured" in BKP and NYT

\begin{tabular}{lcl}
\hline & BKP & NYT \\
\hline Frequency & 14 & 4 \\
Ranking & 75 & 379 \\
\hline
\end{tabular}

\section{Meanings in Dictionary}

The dictionary is used to figure out why these two words are used with totally different frequencies in BKP and NYT. Oxford Advanced Learners Dictionary the 8th Edition is used as the standard dictionary in the study.

Wound (n.)- 1. an injury to part of the body, especially one in which a hole is made in the skin using a weapon

2. mental or emotional pain caused by something unpleasant that has been said or done to you

Wounded (adj.)- 1.injured by a weapon, for example in a war

2. feeling emotional pain because of something unpleasant that somebody has said or done

Regarding the word wound, it is noted in the Oxford Advanced Learner Dictionary that the word wound is often used to talk about people being hurt in war or in other attacks which affect a lot of people.

Injured (v.) - 1. to harm yourself or somebody else physically, especially in an accident

2. to damage somebody's reputation, pride, etc

Injured (adj.) - physically hurt

\section{Data Analysis}

The use of the word wounded and injured in BKP and NYT have the intended meanings to illustrate the political situation during the Red Shirt demonstration in 2010. The NYT prefers to use wounded because it contemplates that the situation is like a war.

On the contrary, BKP did not see the situation as worst as NYT see. The word injured used in BKP contains the softer feeling if compared with the word wounded.

\section{2) Protesters-People}

This pair of word occurred in different pairs of news articles, but it shows the different way to call the Red Shirt protesters, depending on how the reporters see the protesters in the certain situations. The study did not use Antconc programme to sort out all occurrences of these two words as the objective of the study of this pair has nothing to do with the frequency and ranking. The different occurrences of the words people used instead of protesters are found in the article about the crackdown on May 19, 2010.

"Some people in the area carried boxes of cellphones and other electronics, presumably from the mall. (NYT1)

This sentence described that some people were stealing IT products from the shopping mall, while the building was set on fire. The reporter used the word people, which means anybody, instead of the specific word such as looters or protesters. Readers may not think that the protesters were doing this action, but someone. Moreover, the main verb used in this sentence - carried - conveyed an ambiguous action as NYT seems not to specify that 
those people were stealing electronic products from the mall. This is the strategy that NYT used in order not to highlight the bad behaviour of the Red Shirt demonstrators.

However, in another news article of the NYT, which deals with the explosion in Silom area, the reporters wrote about the possible situation of the protesters trying to get into the mall. There are two sentences talking about this situation; however, instead of using the word protesters, the reporters chose the word people in these sentences to describe that general people might break into the mall, not the protesters.

Mr. Nattawut Saikua, one of the protest leaders, actually once said on the stage that the Red Shirt demonstrators might steal products and valuable goods if they are forced by the military to disperse them. It is known that Red Shirt leaders said something about this. So, it is presumable that people that were stealing IT products in the mall are the Red Shirt protesters, not just people. But the reporters preferred to use the word people instead of protesters.

"there might be some people who will try to save their lives by seeking shelter inside the malls," said Nattawut Saikua, one of the protest leaders. (NYT6)

"We cannot control people who are trying to survive." (NYT6)

Another sentence using the word people is in the article writing about the clash at the Phan Fa bridge. The sentence is as follow,

People chased and beat them with sticks as tear gas arced through the dark sky above them and billowed at their feet. (NYT4)

The reporters were elaborating the situation during clash at the Phan Fa bridge. The prior sentence is that 'Overwhelmed in the darkness by thousands of protesters wearing red shirts who ran helter-skelter among them, the soldiers fled, crouching behind their plastic shields.' So, it is presumable that the reporters were talking about the soldiers and the red shirt protesters. However, when they described about someone was chasing and beating the soldiers, they chose the word people instead of protesters as the way not to highlight the protesters as the doers of the action.

\section{Data Analysis}

In the aforementioned articles for studying the use of the words protesters and people, the lexical choices demonstrate the way that the reporters would like the readers to see the protesters. In NYT, the occurrences of the word people tend to happen when the reporters wrote about the violent actions. This is likely to be the way that NYT does not highlight the protesters as the doers of violent actions.

\section{Conclusion}

\subsection{Ideology in NYT}

In summary, the underlying ideology of NYT in this study is that it is likely to support the protest that claimed to demand the democracy in Thailand. This ideology is also shaped by the group of readers of NYT, who also shares the same view of democratic system supporters and would like to see other countries respecting the democracy in the same way that the Americans do. The objective of the Red Shirt protesters in bringing back democracy in NYT's view is the right thing to do, regardless of the ways they took action to demand for democracy and how violent the actions were. Because of this view, NYT seems to ignore or hide the bad side or action of the protesters through the use of words choices.

\subsection{Ideology in BKP}

The tone of news report in BKP towards the Red Shirt demonstration mostly was likely to present in the way that the newspaper presents the facts and is likely to support the government side. Unlike NYT, The newspaper may not focus on "democracy" as it did not mention that the protest is the fighting between the middle class and the poor. BKP rather focused on the situation day by day. For the overview of the news articles in BKP, it can be assumed that BKP did not agree with the Red Shirt protesters as they incite violence during their protests, leaving serious damage to the capital city of Thailand. Hence, it is likely to agree with the Thai government in controlling the situation and bringing back peace to the country, seeing from the space in newspaper that have the government side talked directly to the world more than the protester side.

\subsection{Implications of the Study}

Implications of the research are twofold; for journalists and news readers. Regarding the former, journalists will learn that news language will never be neutral. Articles they are writing will unconsciously convey their beliefs, attitudes and values they have towards the situation they are writing about. Hence, journalists have to be aware 
of words and sentences structures they use in news articles. For foreign correspondents, reporting news in any countries that have different social and cultural background with them should be of their concern. Their social and cultural background should not be involved in the news reporting process and influence the way they report any news articles in order to avoid the ideological bias. Since news report in international newspapers have been spread and read by people globally, how the world will have a view towards the situation in any countries depends on the news reports of international media. Whether the situations are right or wrong, foreign correspondents should try to make the news reports more neutral as possible by not viewing or judging the situation from their perspective only.

In regard to news readers, they will have more understanding about news language that does not contain neutral meaning. When readers read news articles, they will be more cautious and do not jump to the conclusions after reading news from only one source.

\section{References}

Bailie, B. (2013). Meaning Making in the News: A Discourse Analysis on Global Protest. Retrieved from http://hdl.handle.net/11129/616

Bell, A. (1991). The Language of News Media. Oxford: Basil Blackwell.

Chirawat Chana. (2011). Comparative Rhetoric of News Reports in Thailand and The USA with a focus on Thai Political Written Discourse. Thammasat University, Bangkok.

Eggins, S. (1994). An Introduction to Systemic Functional Linguistics. London: Continuum.

Fairclough, N. (1995). Media Discourse. London: Edward Arnold.

Fedler, F. (1993). Reporting for the Print Media. New York: Harcourt Brace Javanovich Publishers.

Fowler, R. (1991). Language in the News: Discourse and Ideology in the Press. London: Routledge.

Harris, G., \& Spark, D. (1997). Practical Newspaper Reporting. Oxford: Focal Press.

Kuo, S. -H. (2007). Language as Ideology: Analyzing Quotations in Taiwanese News Discourse. http://dx.doi.org/10.1075/japc.17.2.08kuo

Manning, P. (2001). News and News Sources: A Critical Introduction. London: SAGE Publication.

Paltridge, B. (2006). Discourse Analysis: An Introduction. New York: Continuum.

Pape, S., \& Featherstone, S. (2005). Newspaper Journalism: A Practical Introduction. London: SAGE Publications.

Richardson, J. E. (2007). Analysing Newspaper: An Approach from Critical Discourse Analysis. New York: Palgrave Macmillan.

van Dijk. (1995). In C. Schaffner \& A. Wenden (Eds.), Language and Peace (pp. 17-33). Aldershot: Dartmouth Publishing.

van Dijk, T. (1998). Ideology: A Multidisciplinary Approach. London: SAGE Publication.

\section{Appendix}

Table 1. Text Coding

\begin{tabular}{|c|c|c|c|c|c|}
\hline \multirow{2}{*}{ Events } & \multicolumn{2}{|c|}{ BKP } & \multicolumn{2}{|c|}{ NYT } & \multirow{2}{*}{ Publication date } \\
\hline & Codes & Word counts & Codes & Word counts & \\
\hline May 19 Crackdown & $B K P 1$ & 566 & NYT1 & 1,118 & May 20, 2010 \\
\hline After Phan Fa Clash & $\mathrm{BKP} 2$ & 770 & NYT2 & 911 & April 12, 2010 \\
\hline Before May Crackdown & BKP3 & 890 & NYT3 & 986 & May 18,2010 \\
\hline Clash Phan Fa & BKP4 & 753 & NYT4 & 965 & April 11, 2010 \\
\hline Clash May 14 & BKP5 & 771 & NYT5 & 1,079 & May 15,2010 \\
\hline Explosion Silom & BKP6 & 744 & NYT6 & 858 & April 23, 2010 \\
\hline Democrat Party Disbandment & $B K P 7$ & 648 & NYT7 & 914 & April 13, 2010 \\
\hline Reconciliation Plan & BKP8 & 849 & NYT8 & 868 & May 5, 2010 \\
\hline Reject House Dissolution & BKP9 & 617 & NYT9 & 722 & April 26, 2010 \\
\hline Seh Daeng Shot & BKP10 & 816 & NYT10 & 1,024 & May 14, 2010 \\
\hline Total & & 7,424 & & 9,445 & \\
\hline
\end{tabular}


Table 2. Direct Quotations in BKP

\begin{tabular}{|c|c|c|c|}
\hline Quotations & Government & Protesters & Others \\
\hline $\begin{array}{l}\text { 1. "All terrorists must end their action otherwise the government will use decisive measures against } \\
\text { them," the centre warned. (BKP1) }\end{array}$ & 1 & & \\
\hline $\begin{array}{l}\text { 2. "We decided to end the rally to save lives of the people from more losses," said Mr Natthawut. } \\
\text { (BKP1) }\end{array}$ & & / & \\
\hline 3. "But the red shirts will not give up our fight for democracy." (BKP1) & & / & \\
\hline 4. "There are violent-prone protesters who remain angry," Mr Sathit told a news conference. (BKP1) & / & & \\
\hline $\begin{array}{l}\text { 5. "Returning power to the people will be the best solution to bring happiness to all Thais, regardless } \\
\text { of what colours they subscribe to, and to move the country forward, Thaksin said. (BKP2) }\end{array}$ & & / & \\
\hline $\begin{array}{l}\text { 6. "When we're ready, we'll reach our final goal at the Ratchaprasong intersection. But right now, } \\
\text { there's still a high risk of lots of casualties," the CRES source said. (BKP3) }\end{array}$ & l & & \\
\hline $\begin{array}{l}\text { 7. "Mr Abhisit should not rule out potential talks based on the fact that the earlier rounds failed," he } \\
\text { said. "Even though this may take time, I believe it's better than letting the killings continue." (BKP3) }\end{array}$ & & / & \\
\hline $\begin{array}{l}\text { 8. "Negotiations can happen if the protest stops and its leaders surrender. But if this does not happen, } \\
\text { they [the UDD leaders] should tell the mobs to stop the rioting and the burning of the city and tyres. } \\
\text { As Mr Natthawut said he could issue orders, does this mean that he ordered the mobs to create } \\
\text { violence?" Mr Korbsak asked. (BKP3) }\end{array}$ & / & & \\
\hline $\begin{array}{l}\text { 9. "We will establish the cause of all loss of life," he said, asking parties not to trade accusations } \\
\text { about the cause. (BKP4) }\end{array}$ & / & & \\
\hline $\begin{array}{l}\text { 10. "The government and I are duty-bound to resolve the problems, restore peace and maintain } \\
\text { justice for the country," he said. (BKP4) }\end{array}$ & / & & \\
\hline 11. 'I cannot accept it any more. Red shirt people, please stop. Don't make more trouble." (BKP4) & / & & \\
\hline $\begin{array}{l}\text { 12. "I will take all responsibility for whatever happens," source quoted him (Gen Prayuth) as saying } \\
\text { (BKP4) }\end{array}$ & l & & \\
\hline $\begin{array}{l}\text { 13. "In case they have to shoot to stop protesters from attacking, they are allowed to fire a shotgun } \\
\text { one shot at a time_aiming below the knees. (BKP5) }\end{array}$ & / & & \\
\hline $\begin{array}{l}\text { 14. "In case war weapons are used against them, troops are allowed to fire M16 rifles," said Col } \\
\text { Sansern. (BKP5) }\end{array}$ & / & & \\
\hline 15. "We will stay put on Wireless Road and intensify security at our checkpoints," he said. (BKP5) & / & & \\
\hline $\begin{array}{l}\text { 16. "The security forces are trying to exert more pressure on the protesters without using force and } \\
\text { we have no policy to cause violence in the rally area." (BKP5) }\end{array}$ & / & & \\
\hline 17. "The situation is getting worse_nearly a civil war. The time for talks is over," he said. (BKP5) & & / & \\
\hline $\begin{array}{l}\text { 18. "Prime Minister Abhisit has no right to be in office, even for one more day. Red shirts in the } \\
\text { provinces are warming themselves up and are ready to move at our signal," said Mr Jatuporn. (BKP5) }\end{array}$ & & I & \\
\hline 19. 'The government regrets the loss of lives and those who were injured," he said. (BKP6) & / & & \\
\hline $\begin{array}{l}\text { 20. "We are sorry for the deaths and the injuries and we hope the attackers get arrested," he said. } \\
\text { (BKP6) }\end{array}$ & & / & \\
\hline $\begin{array}{l}\text { 21. "Those who threw bottles and hit us with slingshot were not businessmen and Silom office } \\
\text { workers, but soldiers who disguised themselves as anti-red shirt civilians," Mr Jatuporn said. (BKP6) }\end{array}$ & & / & \\
\hline $\begin{array}{l}\text { 22. "Police have to work harder. When people have conflicts, police cannot simply stand idly," he } \\
\text { said. (BKP6) }\end{array}$ & / & & \\
\hline $\begin{array}{l}\text { 23. "We want the government to come up with a clear and definite resolution on when exactly the } \\
\text { House will be dissolved," UDD leader Natthawut Saikua said. (BKP8) }\end{array}$ & & / & \\
\hline 24. "Once such an agreement is finalised, then we can start talking." (BKP8) & & I & \\
\hline $\begin{array}{l}\text { 25. "If they do not join with us, we will go ahead to achieve the five objectives," Mr Abhisit said. } \\
\text { (BKP8) }\end{array}$ & / & & \\
\hline 26. "It will be left to the UDD to make a decision." (BKP8) & / & & \\
\hline $\begin{array}{l}\text { 27. "I have made a decision in the best interests of the country. My decision will not run counter to } \\
\text { the principle of the rule of law. (BKP8) }\end{array}$ & / & & \\
\hline $\begin{array}{l}\text { 28. "No amnesties will be granted. Those who broke the law must be dealt with," the prime minister } \\
\text { said, saying the reconciliation process would not include offers of amnesties for those wanted on } \\
\text { arrest warrants for criminal offences. (BKP8) }\end{array}$ & / & & \\
\hline $\begin{array}{l}\text { 29. "I am not sure whether it is a serious offer. But I am confident that is not an answer for the } \\
\text { country's problems. I don't get it," the prime minister said at the Centre for the Resolution of } \\
\text { Emergency Situations (CRES). (BKP9)26. "I see it as an attempt [by the red shirt leaders] to create a }\end{array}$ & / & & \\
\hline
\end{tabular}




\begin{tabular}{|c|c|c|c|}
\hline Quotations & Government & Protesters & Others \\
\hline \multicolumn{4}{|l|}{$\begin{array}{l}\text { new image for themselves, particularly among the international community given that they were } \\
\text { engaged in violence in the past few days," he said. (BKP9) }\end{array}$} \\
\hline $\begin{array}{l}\text { 30. "I see it as an attempt [by the red shirt leaders] to create a new image for themselves, particularly } \\
\text { among the international community given that they were engaged in violence in the past few days," he } \\
\text { said. (BKP9) }\end{array}$ & / & & \\
\hline $\begin{array}{l}31 \text { "It is not just about asking the red shirts. We have to be accountable to the whole population for } \\
\text { the future of the country and the democratic system," he said. (BKP9) }\end{array}$ & l & & \\
\hline \multicolumn{4}{|l|}{$\begin{array}{l}\text { 32. "Mr Abhisit and Gen Anupong did not see eye to eye after Gen Anupong recommended political } \\
\text { means to solve the problem," the source said (BKP9) }\end{array}$} \\
\hline $\begin{array}{l}\text { 33. "Mr Abhisit's decision to turn down the UDD proposal showed he wants to use force against } \\
\text { people," he said, adding that a military operation was likely in the next } 48 \text { hours. (BKP9) }\end{array}$ & \multicolumn{3}{|c|}{ / } \\
\hline $\begin{array}{l}\text { 34. "If the death can bring democracy and justice, we are ready to die. We are ready to face it. We are } \\
\text { here to take the bullets," he said. (BKP10) }\end{array}$ & \multicolumn{3}{|c|}{ / } \\
\hline $\begin{array}{l}\text { 35. "Those behind the attack wanted to tell us that even Seh Daeng could be shot, so other red shirt } \\
\text { protesters can be harmed too," Mr Nattawut said. (BKP10) }\end{array}$ & \multicolumn{3}{|c|}{ // } \\
\hline $\begin{array}{l}\text { 36. "If these [other] leaders accept the government's conditions and send the crowds home, we will } \\
\text { fight until we win," he said. (BKP10) }\end{array}$ & \multicolumn{3}{|c|}{ / } \\
\hline $\begin{array}{l}\text { 37. "We will use the trucks as barriers and we will drop firebombs on the armoured vehicles," he } \\
\text { said. (BKP10) }\end{array}$ & \multicolumn{3}{|c|}{ / } \\
\hline Total 37 quotations & $\begin{array}{l}22 \\
(59.46 \%)\end{array}$ & $\begin{array}{c}15 \\
(40.54 \%)\end{array}$ & $\mathbf{0}$ \\
\hline
\end{tabular}

Table 3. Direct Quotation in NYT

\begin{tabular}{|c|c|c|c|}
\hline Quotations & Government & Protesters & Others \\
\hline $\begin{array}{l}\text { 1. "We cannot resist against these savages anymore," Jatuporn Prompan, one of the leaders, said on a } \\
\text { stage inside the protest zone before turning himself in. (NYT1) }\end{array}$ & & / & \\
\hline 2. "Please listen to me!" he pleaded to the crowd. (NYT1) & & I & \\
\hline 3. "Brothers and sisters, I will use the word 'beg.' I beg you. We have to end this for now." (NYT1) & & I & \\
\hline $\begin{array}{l}\text { 4. Nattawut Saikua, shouted: "If the prime minister wants to govern the country on the top of this } \\
\text { wreckage, he should go ahead and kill us all. But if he wants to do the right thing, he should stop the } \\
\text { shooting immediately." (NYT1) }\end{array}$ & & / & \\
\hline $\begin{array}{l}\text { 5. "Keep breathing! Keep breathing," yelled a man running next to the journalist, who appeared } \\
\text { critically wounded. (NYT1) }\end{array}$ & & & I \\
\hline 6. "Everyone feels that our leaders betrayed us," said Wanpamas Boonpun, 39. (NYT1) & & / & \\
\hline 7. "We want democracy. True democracy, free democracy. Why is it so hard, why?" (NYT1) & & / & \\
\hline 8. "We have to love each other," went the lyrics to the pop song. (NYT1) & & & I \\
\hline 9. "We want to see Thais loving each other again, just like we used to." (NYT1) & & & I \\
\hline $\begin{array}{l}\text { 10. "There is no more negotiation," said Jatuporn Prompan, a leader of the protesters, rejecting a } \\
\text { government overture. (NYT2) }\end{array}$ & & I & \\
\hline $\begin{array}{l}\text { 11. "Although the road is rough and full of obstacles, it's our duty to honor the dead by bringing } \\
\text { democracy to this country." (NYT2) }\end{array}$ & & I & \\
\hline 12. "We're committed to make sure that justice is being done," he said (NYT2) & / & & \\
\hline 13. "This land belongs to the people," read a message painted on one vehicle. (NYT2) & & I & \\
\hline 14. "We have agreed to a new round of talks proposed by the Senate because if we allow things to go & & & \\
\hline $\begin{array}{l}\text { on like this, we don't know how many more lives will be lost," said the leader Nattawut Saikua, } \\
\text { speaking at a news conference in the heart of a neighborhood that has been occupied by } \\
\text { demonstrators for six weeks. (NYT3) }\end{array}$ & & I & \\
\hline $\begin{array}{l}\text { 15. "The situation of the last two or three days gave me no choice," he said, referring to his decision } \\
\text { to use force. (NYT4) }\end{array}$ & / & & \\
\hline $\begin{array}{l}\text { 16. "I had to enforce the law. If the government had done nothing, it would have shown its } \\
\text { weakness." (NYT4) }\end{array}$ & / & & \\
\hline $\begin{array}{l}\text { 17. "We deplore this outbreak of political violence in Thailand, our long-term friend and ally, and } \\
\text { urge good-faith negotiations by the parties to resolve outstanding issues through peaceful means." } \\
\text { (NYT4) }\end{array}$ & & & I \\
\hline
\end{tabular}




\begin{tabular}{|c|c|c|c|}
\hline Quotations & Government & Protesters & Others \\
\hline 18. “There's another hero!” (NYT4) & & / & \\
\hline 19. “Tonight we made history," a protest leader, Arisman Pongruangrong, said. (NYT4) & & I & \\
\hline 20. "We defeated the Thai Army with our bare hands." (NYT4) & & I & \\
\hline $\begin{array}{l}\text { 21. "They are tightening a noose on us, but we will fight to the end, brothers and sisters," one leader, } \\
\text { Nattawut Saikua, told the crowd. (NYT5) }\end{array}$ & & I & \\
\hline 22. "We are never scared of the military," he said in English. (NYT5) & & / & \\
\hline $\begin{array}{l}\text { 23. "If they come, we have the right to fight back. We can't just let them kill us and do nothing." } \\
\text { (NYT5) }\end{array}$ & & I & \\
\hline 24. "We are afraid for the soldiers, too," she said. (NYT5) & & I & \\
\hline $\begin{array}{l}\text { 25. "The soldiers are our sons. We are mother, father, sister, brother. So we don't want any of them to } \\
\text { die. Very, very sad. Very, very sad for Thailand." (NYT5) }\end{array}$ & & I & \\
\hline $\begin{array}{l}\text { 26. "Your days are numbered," an army spokesman, Col. Sansern Kaewkamnerd, said Thursday, } \\
\text { addressing the red shirts. (NYT6) }\end{array}$ & I & & \\
\hline $\begin{array}{l}\text { 27. "I'm scared to death," said a tour guide, Samai Moonsang, who was passing on a motorbike when } \\
\text { the first of the explosions occurred. (NYT6) }\end{array}$ & & I & \\
\hline 28. "It happened right in front of me." (NYT6) & & I & \\
\hline 29. “Fight, fight!” (NYT6) & & I & \\
\hline $\begin{array}{l}\text { 30. "there might be some people who will try to save their lives by seeking shelter inside the malls," } \\
\text { said Nattawut Saikua, one of the protest leaders. (NYT6) }\end{array}$ & & I & \\
\hline 31. "We cannot control people who are trying to survive." (NYT6) & & I & \\
\hline 32. "Things will be out of control if a crackdown happens, no matter what plans are," he said. (NYT6) & & I & \\
\hline $\begin{array}{l}\text { 33. "This government's time in power is nearly over," Veera Musikapong, a protest leader, said to } \\
\text { throngs of protesters in the commercial heart of the city. (NYT7) }\end{array}$ & & I & \\
\hline 34. "The situation requires that the problem be solved by politics." (NYT7) & I & & \\
\hline $\begin{array}{l}\text { 35. "If I can stop them, I will. But if it puts us in danger, we will let them be," said Lt. Col. Dejapiwat } \\
\text { Dejsiri, a senior police official at a precinct in the wealthy Sukhumvit area of Bangkok. (NYT7) }\end{array}$ & I & & \\
\hline 36. "It's like there is no law anymore." (NYT7) & I & & \\
\hline $\begin{array}{l}\text { 37. "The system of political parties is on very shaky ground," said Gothom Arya, a former election } \\
\text { commissioner. (NYT7) }\end{array}$ & & & l \\
\hline $\begin{array}{l}\text { 38. "There is no stability." Mr. Gothom, among others, has called for revision of the law that holds an } \\
\text { entire party accountable for electoral offenses. (NYT7) }\end{array}$ & & & I \\
\hline 39. "His Majesty the King has always warned, 'Don't demolish the house,'” Mr. Sumet said. (NYT7) & & & I \\
\hline 40. We have to protect the country." (NYT7) & & & I \\
\hline $\begin{array}{l}\text { 41. "We have reached a consensus to accept the process of reconciliation," said Veera Musikapong, a } \\
\text { protest leader. (NYT8) }\end{array}$ & & & I \\
\hline 42. "This is because we want to spare lives." (NYT8) & & I & \\
\hline 43. "The prime minister's road map is a good one, and it seems like everyone agrees with it," said & & & \\
\hline $\begin{array}{l}\text { Suryasai Katsila, a leader of the opposing yellow shirt pressure group, which generally supports the } \\
\text { government. (NYT8) }\end{array}$ & I & & \\
\hline 44. But he added: "This is just to find a way out. It's not a solution for Thai society." (NYT8) & I & & \\
\hline 45. "I'm not sure whether this will be a solution for the country." (NYT8) & I & & \\
\hline 46. "We should not dissolve because someone threatens us to dissolve it," he said. (NYT8) & I & & \\
\hline $\begin{array}{l}\text { 47. "I am confident that it will not take too long to bring back peace to our society," Mr. Abhisit said } \\
\text { in a nationally televised address Monday evening. (NYT8) }\end{array}$ & I & & \\
\hline 48. "The government will be ready for an election once the country is peaceful." (NYT8) & I & & \\
\hline $\begin{array}{l}\text { 49. "We all want this to end peacefully," said Kwanchai Praphana, one of the protest leaders, in an } \\
\text { interview at the rally site. (NYT8) }\end{array}$ & & & I \\
\hline $\begin{array}{l}\text { 50. "But we are still not sure if this is the proposal from the Democrat party in its entirety and whether } \\
\text { all the coalition partners agree." (NYT8) }\end{array}$ & & & I \\
\hline 51. If the protesters' doubts are eased, he said, "we will take apart the stage and leave." (NYT8) & & & I \\
\hline $\begin{array}{l}\text { 52. "I'm going to stay here until they give us back the power," he said, as he stood in line for one of } \\
\text { the photo ID cards that rally organizers were producing. (NYT8) }\end{array}$ & & & I \\
\hline 53. "If we don't succeed, then there was no point in coming here in the first place." (NYT8) & & & I \\
\hline 54. "I’m bored," Timmuan Padkong, 58, a farmer, whispered with a furtive smile. (NYT8) & & I & \\
\hline 55. "My back hurts." (NYT8) & & 1 & \\
\hline
\end{tabular}




\begin{tabular}{|c|c|c|c|}
\hline Quotations & Government & Protesters & Others \\
\hline 56. “There aren't this many mosquitoes back home," he added. (NYT8) & & 1 & \\
\hline 57. “When I'm back home, I always keep the air-conditioner on in my room.” (NYT8) & & I & \\
\hline 58. "The ultimatum is just aimed at getting the attention of the foreign media." (NYT9) & I & & \\
\hline 59. "Thirty days is out of the question,” Mr. Abhisit said Sunday. (NYT9) & / & & \\
\hline 60. "I don't think this problem can be solved within 30 days." (NYT9) & I & & \\
\hline $\begin{array}{l}\text { 61. He said, "Negotiations must be done to find a solution for most of the country, not just the red } \\
\text { shirts," (NYT9) }\end{array}$ & I & & \\
\hline $\begin{array}{l}\text { 62. "I never reject a political solution, but a political solution must not create a precedent that } \\
\text { intimidation will bring about social change." (NYT9) }\end{array}$ & I & & \\
\hline $\begin{array}{l}\text { 63. "They will do everything to block us from coming here," said Rassamee Pimpila, 56, a school } \\
\text { principal from the northeast. (NYT9) }\end{array}$ & & & I \\
\hline 64. He added: "It's like a war. We have to eat and sleep on the street." (NYT9) & & & / \\
\hline 65. "We won’t use violence," he said, (NYT9) & I & & \\
\hline $\begin{array}{l}\text { 66. "but as I've said earlier, the situation has escalated toward violence, so the military will have to } \\
\text { adjust its measures." (NYT9) }\end{array}$ & I & & \\
\hline 67. "As the prime minister said, if there is anything needed to bring back peace, we'll do it." (NYT9) & / & & \\
\hline $\begin{array}{l}\text { 68. Responding to reports of splits within the military, the general said: "Being a huge organization, } \\
\text { it's possible, but the number isn't significant enough to say that the military is divided. More } \\
\text { importantly, everyone strictly follows orders." (NYT9) }\end{array}$ & I & & \\
\hline $\begin{array}{l}\text { 69. On Sunday, the red shirts displayed a large banner in English that read: "Peaceful protesters not } \\
\text { terrorists." (NYT9) }\end{array}$ & & I & \\
\hline 70. "Seh Daeng has been shot! Seh Daeng has been shot!” (NYT10) & & I & \\
\hline $\begin{array}{l}\text { 71. "I deny!" he cried in English, with a laugh, when asked in an interview on Sunday about the } \\
\text { dozens of bombings that have set Bangkok on edge and about the mysterious black-shirted killers } \\
\text { who escalated the violence on April } 10 \text { that killed } 26 \text { soldiers and civilians. (NYT10) }\end{array}$ & & / & \\
\hline 72. "No one ever saw me.” (NYT10) & & I & \\
\hline 73. The general's last words before being shot were, “The military cannot get in here.” (NYT10) & & I & \\
\hline $\begin{array}{l}\text { 74. "The people won't go home," the general said on Sunday night, as admirers crowded around him } \\
\text { at a McDonald's restaurant in the heart of the protest area. (NYT10) }\end{array}$ & & I & \\
\hline 75. "Just stop? Compromise? All these people, the hard core, they want to stay longer." (NYT10) & & / & \\
\hline 76. “That's why everywhere I go people cheer me and ask for my autograph,” he said. (NYT10) & & / & \\
\hline 77. he said, adding, "There are no rules." (NYT10) & & 1 & \\
\hline 77 quotations & $\begin{array}{c}22 \\
(28.57 \%)\end{array}$ & $\begin{array}{c}47 \\
(61.04 \%)\end{array}$ & $\begin{array}{c}8 \\
(10.39 \%)\end{array}$ \\
\hline
\end{tabular}

\section{Copyrights}

Copyright for this article is retained by the author(s), with first publication rights granted to the journal.

This is an open-access article distributed under the terms and conditions of the Creative Commons Attribution license (http://creativecommons.org/licenses/by/3.0/) 